\title{
O DIREITO À OBJEÇÃO DE CONSCIÊNCIA À EXPERIMENTAÇÃO ANIMAL EM PRÁTICAS DIDÁTICAS
}

\author{
THE RIGHT TO THE OBJECTION OF AWARENESS \\ TO ANIMAL TESTING PRACTICES IN TEACHING
}

\author{
NINA TRÍCIA DISCONZI RODRIGUES ${ }^{1}$ \\ ADRIANE DE FREITAS FERRARI ${ }^{2}$
}

\begin{abstract}
RESUMO: Este trabalho trata da objeção de consciência à experimentação animal manifestada por acadêmicos que se escusam em participar de aulas que utilizem o modelo animal como método de ensino, sob a alegação de que este tipo de prática ofende as suas convicções filosóficas e morais. O presente estudo, além de abordar o direito à objeção de consciência como um instrumento eficaz à concretização do direito fundamental à liberdade de consciência, previsto no artigo $5^{\circ}$, inciso VI, da Constituição da República Federativa do Brasil de 1988, também enfrenta a questão sobre a real necessidade da utilização da vivissecção em animais não humanos como forma de adquirir conhecimento, considerando a existência de métodos substitutivos com os mesmos efeitos didáticos. Apesar das universidades gozarem de autonomia didático-científica, essa garantia encontra limites em direitos mais relevantes, como o direito dos estudantes em não participar de aulas de vivissecção em animais, as quais, segundo eles, afrontam suas consciências e suas dignidades. Com efeito, no caso da experimentação em animais, a objeção de consciência como direito fundamental deve ser garantida e atendida quando apresentada pelo objetor.
\end{abstract}

PALAVRAS-CHAVE: Objeção de Consciência; Liberdade de Consciência; Experimentação Animal; Vivissecção.

\begin{abstract}
This paper deals with conscientious objection to animal experimentation manifested by academics that excuse to participate in classes using the animal model as a method of education, on the grounds that this practice offends your moral and philosophical convictions. The present study in addition to addressing the right to conscientious objection as an effective tool for achieving the fundamental right to freedom of conscience, as provided in Article 5, paragraph $\mathrm{VI}$
\end{abstract}

\footnotetext{
Artigo recebido em 09.05.2013. Pareceres emitidos em 08.09.2013, 09.09.2013 e 10.03.2014. Artigo aceito para publicação em 07.04.2014.

${ }^{1}$ Doutora em Direito pela Universidade de São Paulo. Professora de Direito na Faculdade FACENSA (Faculdade Cenesista de Gravataí). Advogada em Porto Alegre/RS. ninadisconzi@uol.com.br

2 Bacharela em Direito - Centro Universitário Ritter dos Reis - UniRitter, Canoas/RS. Servidora Pública em Porto Alegre/RS. adriane.ferrari@gmail.com
} 
of the Constitution of the Federative Republic of Brazil in 1988, also faces the question of the real necessity of the use of nonhuman animals in vivisection as a means of acquiring knowledge, considering the existence of methods with the same effects substitute teaching. Although universities enjoy autonomy didacticscientific, this guarantee find limits in rights more relevant, as the right of students not to attend classes of animals in vivisection, which according to them, confront their consciences and their dignity. Indeed, in the case of animal experimentation, the conscientious objection as a fundamental right guaranteed and should be answered when presented by the objector.

KEYWORDS: Conscientious Objection; Freedom of Conscience; Animal Experimentation; Vivessection.

SUMÁRIO: Introdução; 1 . Sobre a Liberdade de Consciência; 1.1 Conceito e Características da Objeção de Consciência; 1.2 Breves Considerações Históricas sobre a Objeção de Consciência; 1.3 Direito à Objeção de Consciência como Direito Fundamental; $1.4 \mathrm{O}$ Direito à Objeção de Consciência na Legislação Internacional; 2. Da Experimentação em Animais; 2.1 Retrospectiva Histórica da Experimentação Animal; 2.2 A Vivissecção como Método Didático Padrão; 3. A Colisão de Direitos Fundamentais; Conclusão; Referências.

SUMMARY: Introduction; 1. About Freedom of Conscience; 1.1 Concept and Characteristics of the Conscientious Objection; 1.2 Summary Historic of the Conscientious Objection; 1.3 The Right to the Conscientious Objection; 1.4 The Right to the Conscientious Objection in International Law; 2. The Animal Trials; 2.1 Historical of the Animal Trials; 2.2 The Vivisection Teaching as a Method Standard; 3. The Conflict of Fundamental Rights; Conclusion; References.

\section{INTRODUÇÃO}

No Brasil, a polêmica sobre o direito à objeção de consciência à experimentação animal ganhou repercussão nacional a partir da ação judicial promovida pelo estudante do curso superior de Ciências Biológicas, Róber Bachinski, contra a Universidade Federal do Rio Grande do Sul. Nessa medida, investiga-se no presente trabalho a possibilidade dos estudantes acadêmicos das áreas biomédicas, através do direito à objeção de consciência, escusarem-se de realizar aulas práticas de vivissecção em animais por motivos de convicções filosóficas, morais e éticas e, em contrapartida, terem o direito à substituição desse método por outros que resultem nos mesmos efeitos didáticos e não submetam os animais à crueldade. Com a repercussão da referida ação judicial, começou-se a repensar sobre a real necessidade do uso de animais para esse fim, considerando a existência de outros métodos. A vivissecção, por ser uma prática muito antiga, hoje é considerada por muitos estudiosos e pesquisadores como ultrapassada. Mesmo assim, foi adotada por inúmeras faculdades das áreas biomédicas como o principal método para adquirir conhecimento, e até hoje muitas delas ainda a utilizam, mesmo com a gama de métodos alternativos disponíveis.

Considerando a evolução da consciência da humanidade e o progresso na ciência, analisa-se o que a atual legislação sobre a experimentação animal aborda, tanto em âmbito nacional como em âmbito internacional. Outrossim, busca-se identificar os argumentos morais e éticos contrários ao modelo animal 
e o porquê de a maioria dos estudantes acabar adotando um comportamento acrítico e uma suposta falta de questionamento ao presenciar tais aulas. O conjunto dessas abordagens tem proporcionado uma crescente discussão, principalmente no âmbito acadêmico, sobre a verdadeira necessidade do uso de animais em disciplinas curriculares, e no meio jurídico reforça os argumentos a favor do reconhecimento do direito à objeção de consciência. Posteriormente, trata-se da objeção de consciência aplicada à experimentação animal. Com o intuito de elucidar esse assunto tão controverso, apresenta-se o conceito e as características da objeção de consciência, bem como a sua presença no contexto internacional.

Vale ressaltar que o enfoque aqui apresentado é a sua aplicação à experimentação animal. Assim, não se examinam outros casos de objeção de consciência como, por exemplo, o direito à objeção de consciência ao serviço militar, tendo em vista a proteção constitucional deste direito que está disposto de forma específica no artigo 143, § $1^{\circ}$ da Constituição Federal de 1988. Nessa medida, o direito à objeção de consciência à experimentação animal, assim como em outros tipos, está compreendido de forma genérica no artigo $5^{\circ}$, inciso VIII, da Constituição Federal, o qual dispõe que ninguém será privado de direitos por motivo de crença religiosa ou de convicção filosófica ou política, salvo se as invocar para eximir-se de obrigação legal a todos imposta e recusar-se a cumprir prestação alternativa, fixada em lei.

Igualmente, considerando essa falta de previsão legal específica sobre o direito à objeção de consciência na experimentação animal, analisam-se os fundamentos e as justificativas para o reconhecimento deste direito. Examina-se, ainda, o seu aspecto constitucional, como sendo um direito fundamental, pois além de ser uma consequência do direito à liberdade de consciência (artigo $5^{\circ}$, inciso VI, da Constituição Federal), a objeção está intimamente ligada ao princípio da dignidade da pessoa humana (artigo $1^{\circ}$, inciso $\mathrm{III}$, da Constituição Federal).

\section{SOBRE A LIBERDADE DE CONSCIÊNCIA}

Entende-se por consciência, segundo o filósofo MORA (1998, p. 620), a percepção e o reconhecimento de algo exterior, como um objeto, uma qualidade, uma situação, dentre outros. A consciência é como o sentimento ou conhecimento que permite ao ser humano vivenciar, experimentar e compreender aspectos ou a totalidade de seu mundo interior (HOUAISS; VILLAR, 2009, p. 1371). Nesse passo, a liberdade de consciência é aquela de foro íntimo, a qual a Constituição Federal de 1988 em seu artigo $5^{\circ}$, inciso $\mathrm{VI}^{3}$,

\footnotetext{
${ }^{3}$ Art. $5^{\circ}$ Todos são iguais perante a lei, sem distinção de qualquer natureza, garantindo-se aos brasileiros e aos estrangeiros residentes no País a inviolabilidade do direito à vida, à liberdade, à igualdade, à segurança e à propriedade, nos termos seguintes. VI - é inviolável a liberdade de consciência e de crença, sendo assegurado o livre exercício dos cultos religiosos e garantida, na forma da lei, a proteção aos locais de culto e a suas liturgias. BRASIL. Constituição (1988). Constituição da República Federativa do Brasil de 1988. Disponível em: <http://www.planalto.gov.br/ ccivil_03/constituicao/constituiçao.htm>. Acesso em: 12 mar. 2013.
} 
declara como inviolável, e enquanto interiorizada é condicionável por meios variados, mas sempre livre, pois nenhum indivíduo pode ser obrigado a pensar de modo diferente.

Outrossim, como bem apontado por Sampaio Dória, citado por José Afonso da Silva (2008, p. 241), a liberdade de consciência é a liberdade de conteúdo e supõe, ainda, o contato do indivíduo com seus semelhantes, através do qual compartilha os seus conhecimentos e opiniões, tanto políticas quanto religiosas, bem como suas crenças e sua concepção de mundo. De outro modo, cabe referir que o direito à liberdade de consciência encontra-se firmado como direito fundamental. Este direito está diretamente ligado ao conceito de pessoa humana e de sua própria personalidade (MORAES, 2006, p. 25). O supramencionado inciso VI do artigo $5^{\circ}$ da Constituição brasileira encontra-se inserido no Título II - "Direitos e Garantias Individuais e Coletivos" - os quais possuem nítida função de proteger os cidadãos contra o arbítrio estatal (MARMELSTEIN, 2009, p. 78).

Por fim, é considerado integrante da primeira "geração" dos direitos que, como o próprio termo indica, são os grandes momentos de conscientização em que reconhecem "famílias" de direitos, tendo características comuns e peculiares (FERREIRA FILHO, 2007, p. 06). A primeira "geração" dos direitos seria a dos direitos civis e políticos, fundamentados na liberdade, que tiveram origem com as revoluções liberais (MARMELSTEIN, 2009, p. 40). A reivindicação das revoluções liberais era por uma maior liberdade individual frente ao Estado, além da contestação frente ao autoritarismo dos governantes (SILVA, 2008, p. 149-151).

Cabe também referir que Celso Ribeiro Bastos e Samantha Pflug (2001, p. 107) fazem uma importante diferenciação entre a liberdade de consciência e a de crença, no sentido de que uma consciência livre pode determinar-se na acepção de não ter crença alguma. Por outro lado, a liberdade de consciência pode levar a uma adesão a certos valores morais e espirituais que não passam por sistema religioso algum. O autor exemplifica esta questão apontando os movimentos pacifistas que, embora tendo por motivo um apego à paz e ao banimento da guerra, não implicam em uma fé religiosa. Pontes de Miranda (1963, p. 445), nesta mesma linha de raciocínio, afirma que "a liberdade de consciência e de crença são inconfundíveis. O descrente também tem a liberdade de consciência e pode pedir que se tutele, juridicamente, tal direito."

Cabe, ainda, ressaltar que o respeito à inviolabilidade do direito à liberdade de consciência cabe à coletividade e a cada pessoa como uma obrigação, no sentido de não interferir no aspecto interno da personalidade de outrem, tendo em vista o conjunto individualizador do ser, com suas ideias, suas concepções e convicções. Por conseguinte, não se pode impedir ou desvirtuar esse conjunto formador do interno psíquico de cada pessoa, a não ser por convencimento próprio natural (BITTAR, 2000, p. 115-116). Dessa feita, a Constituição Federal traz de forma explícita que a consciência é inviolável, 
e que isso não se traduz numa mera expressão textual, redigida com a finalidade de ser compreendida facilmente, mas explica que a proteção que se dá é tanto para a consciência quanto para a exteriorização dela.

\subsection{Conceito e Características da Objeção de Consciência}

Define-se objeção de consciência como uma pretensão de direito individual com o fim de recusar-se a cumprir obrigação jurídica imposta pelo Estado a todos, sob o fundamento de serem deveres incompatíveis com as convicções morais, políticas e filosóficas (BUZANELLO, 2006, p. 150). Como bem asseveram Canotilho e Moreira (apud MORAES, 2009, p. 120):

[...] a objeção de consciência se constitui no direito do sujeito de não cumprir obrigações ou não praticar atos que conflituem essencialmente com os ditames da consciência de cada um.

Com efeito, passa-se a analisar brevemente os requisitos característicos da objeção de consciência. Num primeiro momento verifica-se que a recusa de obediência a uma norma jurídica, a oposição à submissão a uma diretriz de uma autoridade pública ou, ainda, a rejeição a uma proposta ou comportamento imposto são os traços mais característicos da objeção de consciência. Isso demonstra a dimensão externa, sendo a mais notória em termos sociais, que representa precisamente a sua faceta mais polêmica e que causa maior reação e impacto na opinião pública. Em segundo lugar, essa recusa ou rejeição fundamenta-se em motivos ou razões invocadas pelo foro íntimo do objetor, sendo baseados nas clássicas questões de ordem religiosa, filosófica e moral. Não obstante, a esses dois requisitos indispensáveis acrescenta-se um terceiro elemento, o qual pode também caracterizar o comportamento do objetor, pois se trata da utilização da não violência como método de atuação. Ocorre que este terceiro elemento não constitui sempre e necessariamente um dos requisitos constitutivos da objeção de consciência (CORREIA, 1989, p. 18).É necessário ressaltar, ainda, que o núcleo da objeção de consciência é a liberdade de consciência, pois reflete a liberdade de crença e de pensamento (BUZANELLO, 2006, p. 151).

Nessa medida, pode-se afirmar que o direito à objeção de consciência é uma consequência necessária da liberdade de consciência, constituindo, portanto, uma norma especial, a qual deve ser prioritariamente aplicada, prevalecendo sobre a norma geral que constitui o princípio da igualdade. Por essa razão, alguns entendem que a objeção de consciência poderia ferir o princípio da igualdade, sob o argumento de que configuraria um privilégio ou um benefício para poucos (CORREIA, 1989, p. 64-65). Entretanto, tal argumento não prospera, pois como bem demonstrado por António Damasceno Correia (1989, p. 65), o fato de um indivíduo se recusar a cumprir uma obrigação em virtude de uma objeção de consciência não vislumbra obrigatoriamente violação ao princípio da igualdade, sendo que, na verdade, o que se busca é a efetivação deste princípio. Isso pode, à primeira vista, parecer um privilégio, 
mas em realidade a Constituição Federal, ao atender essas situações, quis restringir o princípio da igualdade para, então, concretizá-lo.

Cláudio Maraschin (2007, p. 2) assevera que não é razoável imaginar que o princípio da igualdade restaria afetado pelo fato da previsão legal da objeção da consciência, tampouco que este direito signifique a criação de qualquer privilégio ou benefício. A regulamentação de alternativas à obrigação principal objetada seria o suficiente para refutar o argumento desfavorável à objeção. Todavia, apesar das inquietações provocadas por estes argumentos desfavoráveis à objeção de consciência, é necessário reafirmar o seu valor enquanto elemento indispensável à convivência democrática. O direito à objeção de consciência não apenas não viola o princípio da igualdade, como é precisamente em nome deste princípio que faz sentido falar em objeção de consciência. Se todos os cidadãos têm a mesma dignidade social, como prescreve o princípio da igualdade (artigo $5^{\circ}$, caput da Constituição) e nenhum destes cidadãos pode ser prejudicado ou privado de qualquer direito em virtude de motivo religioso, convicção política, filosófica ou ideológica (nos termos do princípio da não discriminação do artigo $3^{\circ}$, IV da Constituição ${ }^{4}$ ) não haverá fundamento mais legítimo, senão este, para isentar o objetor de consciência de uma atividade ou função a qual a sua consciência se opõe ou rejeita (MARASCHIN, 2007, p. 2).

Portanto, é especialmente em virtude do princípio da igualdade que o objetor terá o direito ao reconhecimento da sua liberdade de manifestar-se enquanto objetor. Somente assim faz sentido falar na plenitude da efetivação e realização da liberdade de consciência, como corolário do direito à objeção de consciência (MARASCHIN, 2007, p. 2-3).

\subsection{Breves Considerações Históricas sobre a Objeção de Consciência}

$\mathrm{Na}$ Grécia Antiga a noção de consciência moral era praticamente desconhecida. Contudo, foi através de Sófocles, em especial na sua obra, Antígona, que se abordou pela primeira vez no pensamento grego a questão sobre a possibilidade de o cidadão rebelar-se contra as normas ditadas pelos governantes (CORREIA, 1989, p. 33). Nessa linha, com o Cristianismo na Idade Média, surgiram inevitáveis conflitos entre a consciência moral de cada indivíduo e a vontade dos governantes. Quando o poder era concentrado nas mãos do Império Romano, a Igreja posicionou-se frontalmente contra, a fim de instituir um domínio reservado à sua própria jurisdição. Dessa forma, a objeção de consciência pregada pela Igreja assumia duas formas: objeção ao serviço com armas e, ainda, objeção à prestação de culto ao imperador no período medieval. (CORREIA, 1989, p. 33-34).

\footnotetext{
${ }^{4}$ Art. $3^{\circ}$ Constituem objetivos fundamentais da República Federativa do Brasil: IV - promover o bem de todos, sem preconceitos de origem, raça, sexo, cor, idade e quaisquer outras formas de discriminação. BRASIL. Constituição (1988). Constituição da República Federativa do Brasil de 1988. Disponível em: <http://www.planalto.gov.br/ccivil_03/constituicao/constituiçao.htm>. Acesso em: 12 mar. 2013.
} 
Não obstante, o primeiro discurso breve a favor da objeção de consciência se deu no século XV, com a obra do humanista católico holandês Erasmo de Rotterdan. Já no século XVI, com a reforma protestante de Martinho Lutero, diversas igrejas foram criadas, sendo que estas se mantiveram fiéis ao princípio da objeção de consciência e da não violência em geral (CORREIA, 1989, p. 35).Entretanto, foi em 1793 que surgiu a primeira afirmação do direito à objeção de consciência em texto escrito, através de um Decreto permitindo aos anabatistas a dispensa do serviço militar pela invocação de fortes motivos religiosos.

No século XIX, um marco importantíssimo foi a obra "A Desobediência Civil", do americano Henry David Thoreau, além da propagação deste direito pelas legislações dos Estados contemporâneos (CORREIA, 1989, p. 36). Por outro lado surgiram, no século $X X$, muitos personagens significativos, os quais contribuíram decisivamente para implantação de novas perspectivas de tolerância e de aceitação do direito à objeção (CORREIA, 1989, p. 39). Gandhi, por exemplo, foi um desses personagens. Ele encetou sua objeção visando à independência da Índia e contra o governo colonial britânico, difundiu a não violência, a não colaboração e a desobediência civil (CORREIA, 1989, p. 39).O italiano Lanza Del Vasto, seguidor de Mohandas Gandhi, conheceu da sua mensagem e decidiu pregá-la e consagrá-la pelo Ocidente. Para Lanza, o objetor é um "mártir" dotado de enorme coragem (DEL VASTO, 1978, p. 63-89). Lanza ainda afirma que:

[...] o solitário, obscuro e silencioso sacrifício dos objetores de consciência em todos os países da Europa e da América não conseguirá resolver o problema da guerra, pois o exército é apenas instrumento dela... Conseguirão pelo menos obrigar a conhecer um direito fundamental do homem, que as democracias espezinham mais do que fizeram os impérios bárbaros: o direito a não matar.

Outro mártir que sucumbiu ao combate em defesa da liberdade e dos direitos cívicos foi Martin Luther King, o que acabou lhe rendendo o Prêmio Nobel da Paz em 1964. No Estado do Alabama, nos Estados Unidos da América, Luther King foi o porta-voz dos negros da localidade, que eram vítimas de discriminação e humilhações constantes. Pregava a não cooperação e a resistência não violenta (CORREIA, 1989, p. 42-43). No Brasil, o bispo Dom Helder era conhecedor da miséria no Nordeste, assim como em outras partes do mundo, e frente à desigualdade social afirmava que todos deveriam objetar frente às injustiças nas relações internacionais (CORREIA, 1989, p. 39).

\subsection{Direito à Objeção de Consciência como Direito Fundamental}

Como visto anteriormente, a Constituição Federal de 1988 consagrou em seu artigo $5^{\circ}$, inciso $\mathrm{VI}$, o direito à liberdade de consciência e, ainda, que a proteção a esse direito se estende tanto à consciência quanto à exteriorização dela. Outrossim, viu-se que o direito à objeção de consciência é uma 
consequência necessária da liberdade de pensamento. Igualmente, a ideia de objeção de consciência envolveria o elemento mais íntimo, mais nuclear ou mais essencial da personalidade, considerando ser a consciência a conformação ética do ser - uma espécie de "voz de si mesmo" (MARASCHIN, 2007, p. 5).

É oportuno referir que as Constituições brasileiras, em regra, sempre asseguraram a liberdade de pensamento, contudo nem sempre o seu pleno exercício foi possível, como ocorreu nos períodos não democráticos ou marcados pela intolerância religiosa. Pinto Ferreira, citado por José Carlos Buzanello (2001, p. 175), destaca que no regime constitucional de 1946, o artigo 141 previa a inviolabilidade do direito à liberdade, porém a Escola Politécnica da Pontifícia Universidade Católica do Rio de Janeiro vedou a rematrícula de diversos alunos, pois eles não professaram a fé católica; tal fato ainda foi ratificado por órgão do Judiciário.

Apesar do avanço da atual Constituição com relação às ordens jurídicas anteriores, verifica-se que o reconhecimento do direito à liberdade de consciência deu-se de forma limitada, pois, concretamente, mesmo com o alcance da proteção, o legislador preocupou-se tão somente com o serviço alternativo relacionado à obrigatoriedade do serviço militar, assim disposto no artigo 143, $\S 1^{0^{5}}$. Não obstante, o reconhecimento, mesmo precário, representou um primeiro e importante passo e teve a virtude de alertar a opinião pública para um direito fundamental que reclama efetividade (MARASCHIN, 2007, p. 9). É necessário referir, ainda, que esse autor aduz que este direito fundamental garantido pela Constituição está estabelecido tanto de forma específica (artigo $143, \S^{\circ} 1^{\circ}$ quanto de forma genérica (artigo $5^{\circ}$, VIII). A forma específica abrange a obrigatoriedade do serviço militar e a forma genérica envolve outras espécies.

Bruno Heringer Júnior (2004, p. 14) observa que, na forma genérica deste direito fundamental, a Constituição brasileira forneceu um importante norte ao dispor, em seu artigo $5^{\circ}$, inciso VIII, que "ninguém será privado de direitos por motivo de crença religiosa ou de convicção filosófica ou política, salvo se as invocar para eximir-se de obrigação legal a todos imposta e recusar-se a cumprir prestação alternativa, fixada em lei". Do dispositivo mencionado, parece clara a opção do constituinte pelo oferecimento de alternativas legais ao objetor de consciência; ou seja, foi imposta ao legislador ordinário a obrigação de, ao criar mandados ou proibições jurídicas, considerar possíveis manifestações individuais divergentes fundadas em convicções morais, possibilitando isenções sem privilégios.

\footnotetext{
${ }^{5}$ Artigo 143. O serviço militar é obrigatório nos termos da lei. § $1^{\circ}$ Às Forças Armadas compete, na forma da lei, atribuir serviço alternativo aos que, nos tempos de paz, após alistados, alegarem imperativo de consciência, entendendo-se como tal o decorrente de crença religiosa e de convicção filosófica ou política, para se eximirem de atividades de caráter essencialmente militar. BRASIL. Constituição (1988). Constituição da República Federativa do Brasil de 1988. Disponível em: <http://www.planalto.gov.br/ccivil_03/constituicao/constituiçao.htm>. Acesso em: 12 mar. 2013.
} 
$\mathrm{Na}$ Constituição brasileira de 1988, os direitos e garantias fundamentais estão previstas em seu Título II, subdivididos em cinco capítulos, abrangendo dos artigos $5^{\circ}$ ao $17^{\circ}$ (MORAES, 2006, p. 25). Nesse tom, ao formular o texto constitucional, percebe-se que o constituinte conferiu uma posição topográfica privilegiada aos direitos fundamentais, colocando-os logo nos artigos iniciais. Isso se deve a uma simbólica demonstração de prestígio (MARMELSTEIN, 2009, p. 67).

Nesse passo, nota-se que, estando a liberdade de consciência delineada enquanto direito fundamental na atual ordem constitucional brasileira, importa lembrar que a ação ou instrumento de garantia desta, capaz de torná-la eficaz, é a objeção de consciência (MARASCHIN, 2007, p. 10). Dessa feita, ela se destina como instrumento hábil à realização da liberdade de consciência, nas situações em que colidir com outros valores igualmente protegidos (MARASCHIN, 2007, p. 1).Deve-se dar a necessária proteção à consciência, por ser elemento essencial do ser humano, pois não é possível haver respeito e proteção do livre desenvolvimento da personalidade sem amparar a sua liberdade, ou seja, é impossível defender a integridade moral do indivíduo sem garantir a integridade da sua consciência (MARASCHIN, 2007, p. 5).

Assim, o reconhecimento constitucional da liberdade de consciência, como direito geral, pode implicar limitação à coatividade do Direito, já que até mesmo as regras - que descrevem imediatamente a conduta devida - são apenas preliminarmente decisivas. Vale dizer que, mesmo que tenham suas condições de aplicabilidade preenchidas, ainda assim podem não ser aplicadas, considerando as razões excepcionais que superem a própria razão que sustenta a aplicação normal da regra (HERINGER JÚNIOR, 2004, p. 10). Por outro lado, o direito à objeção de consciência está intimamente ligado ao princípio da dignidade da pessoa humana, conforme lição de Ingo Wolfgang Sarlet (2002, p. 47):

[...] a dignidade da pessoa humana é simultaneamente limite e tarefa dos poderes estatais e, no nosso sentir, da comunidade em geral, de todos e de cada um, condição dúplice esta que também aponta para uma paralela e conexa dimensão defensiva e prestacional de dignidade. Como limite, a dignidade implica não apenas que a pessoa não pode ser reduzida à condição de mero objeto da ação própria e de terceiros, mas também o fato de a dignidade gerar direitos fundamentais (negativos) contra atos que a violem ou a exponham a graves ameaças. Como tarefa, da previsão constitucional (explícita ou implícita) da dignidade da pessoa humana, dela decorrem deveres concretos por parte de tutela por parte dos órgãos estatais, no sentido de proteger a dignidade de todos, assegurando-lhe também por meio de medidas positivas (prestações) o devido respeito e promoção.

Depreende-se, portanto, que a liberdade de consciência relaciona-se com a dignidade da pessoa humana, valor expressamente elencado no artigo $1^{\circ}$, 
inciso III, da Constituição Federal do Brasil ${ }^{6}$, como sendo um dos fundamentos do Estado. Revela-se, assim, como pressuposto de um Estado que se pretende instrumental do livre desenvolvimento da personalidade. Ao tratar a pessoa humana como fim, e não como meio, como sujeito, e não como objeto, o Estado Democrático de Direito busca proteger não apenas a sua vida corpórea, mas também favorecer a procura pela própria felicidade (HERINGER JÚNIOR, 2004, p. 10).

Dessa maneira, no caso de não proteção à liberdade de consciência, ou seja, o não atendimento à garantia da objeção de consciência estaria, assim, violado este direito fundamental, bem como o princípio da dignidade da pessoa humana. Se a objeção de consciência favorece o pleno desenvolvimento da vida, da dignidade e da liberdade - que são direitos fundamentais de primeira ordem - ela deve ser não apenas respeitada, mas também converter-se em obrigação ou dever ético quando ameaçada. Afinal, a atitude pessoal de não estar de acordo é essencial ao ser humano, pois o enriquece tornando-o um elemento dinamizador na sociedade pluralista. Uma sociedade sem dissenso é uma sociedade totalitária (MARASCHIN, 2007, p. 6).

Segundo Norberto Bobbio (2000, p. 53-78), o dissenso é característica essencial dentro de uma democracia pluralista, pois o dissenso não é destruidor da sociedade, mas estimulante. Ele ainda complementa suas observações afirmando que por sistema democrático se entende, hoje, como um conjunto preliminar de regras procedimentais, das quais a regra da maioria é a principal, mas não a única. Nesse passo, pluralismo ideológico é considerado pelo filósofo Edgar Morin (2001, p. 109) como elemento imprescindível para a existência de uma sociedade pluralista democrática, visto que o estabelecimento de um consenso sobre certas questões configura-se como um elemento necessário a qualquer sociedade democrática. Porém, isso não é suficiente, necessário que o pluralismo esteja presente, pois ele nutre a democracia com conflitos de ideias e opiniões, que lhe conferem vitalidade.

Com relação à liberdade de consciência, o filósofo John Rawls (1997, p. 64) a compreende como uma liberdade básica devendo ser, assim, acessível a todos e distribuída de forma igual aos cidadãos de uma determinada sociedade, tendo em vista o seguinte princípio de justiça: "cada pessoa deve ter um direito igual ao mais abrangente sistema de liberdades básicas iguais que seja compatível com um sistema semelhante de liberdades para as outras". Ele também afirma que, considerando as características do princípio de justiça retro, o mais conveniente seria atribuir igualmente a todos o direito de exercer a liberdade de consciência, pois esta seria a única forma de

\footnotetext{
${ }^{6}$ Art. $1^{\circ}$ A República Federativa do Brasil, formada pela união indissolúvel dos Estados e Municípios e do Distrito Federal, constitui-se em Estado Democrático de Direito e tem como fundamentos. III - a dignidade da pessoa humana. BRASIL. Constituição (1988). Constituição da República Federativa do Brasil de 1988. Disponível em: <http://www.planalto.gov.br/ccivil_03/constituicao/ constituiçao.htm>. Acesso em: 12 mar. 2013.
} 
assegurar que o conteúdo particular de cada indivíduo fosse respeitado, sem que a crença de um se sobrepusesse à do outro (RAWLS, 1997, p. 223).

A consciência, protegida pelo direito através da liberdade de consciência, não raras vezes entra no jogo da colisão de direitos que podem se produzir entre distintas normas de um ordenamento jurídico, mesmo entre aquelas que protegem direitos fundamentais, devido às diferentes fontes das quais os mesmos emanam. Neste choque de direitos é que se acende a chama da objeção de consciência, desde o âmbito do direito positivo adquirindo, assim, uma forma jurídica (MARASCHIN, 2007, p. 10).

Nesse prisma, é incontestável que exista um direito geral à objeção de consciência - não absoluto, evidentemente -, decorrência do reconhecimento do direito fundamental à liberdade de consciência e dos demais dispositivos constitucionais sobre o assunto, já antes apontados (HERINGER JÚNIOR, 2004, p. 16). Por essa razão, a escusa de consciência se aplica às obrigações de forma genérica, e não somente ao serviço militar obrigatório (MORAES, 2006, p. 124).

\subsection{O Direito à Objeção de Consciência na Legislação Internacional}

A previsão legal do direito à objeção de consciência é uma conquista contemporânea, pois as primeiras disposições a título individual com o objetivo de regulamentar a situação criada pelos objetores de consciência surgiram no princípio do século XX. Países como a Noruega (1902) e a Austrália foram os percursores (CORREIA, 1989, p. 96).

Nesse passo, verifica-se que a partir do século $X X$, com o advento da Segunda Guerra Mundial, sentiu-se a necessidade de reconhecer novos direitos fundamentais. Por esta razão, os Estados começaram a inserir nos seus respectivos ordenamentos jurídicos preceitos constitucionais que consagraram o direito à objeção de consciência (CORREIA, 1989, p. 96).

Nessa medida, o ponto de partida deu-se na Organização das Nações Unidas, a qual teve papel de extrema importância, pois, em 1945, assinou-se a Carta das Nações Unidas, que proclamou e reafirmou logo no seu preâmbulo a fé nos direitos humanos e na dignidade. Por conseguinte, com base nos objetivos da referida Carta, em 1948, foi adaptada a famigerada Declaração Universal dos Direitos do Homem pela Assembleia Geral das Nações Unidas. Tal Declaração foi ratificada pelo Brasil na mesma data e, em seu artigo 18, assim estipulou (CORREIA, 1989, p. 90):

Art. 18. Toda pessoa tem direito à liberdade de pensamento, de consciência e de religião; este direito implica a liberdade de mudar de religião ou de convicção, assim como a liberdade de manifestar a religião ou convicção, sozinho ou em comum, tanto pública como em privado, pelo ensino, pela prática, pelo culto e pelos ritos.

Em 1966, o Pacto Internacional de Direitos Cívicos e Políticos foi mais além. O Pacto salvaguardou a garantia de se poder optar por qualquer religião 
ou conviç̧ão sem qualquer coação. Este documento foi ratificado pelo Brasil em 1992. Mais tarde, em 1975, como importante marco no âmbito dos direitos do homem, a Conferência de Helsinque sobre a Segurança e a Cooperação na Europa aprovou documento no qual reafirmava o direito a liberdade de pensamento, consciência, religião ou crença (CORREIA, 1989, p. 90).

Nesse tom, as entidades internacionais em prol da defesa do direito à objeção de consciência, dentre elas a Comissão Internacional de Juristas, a UNESCO e a Comissão dos Direitos do Homem das Nações Unidas, contribuíram de forma decisiva para que diversos Países reconhecessem - pelo menos por alguns dos motivos - este direito. Mencionam-se alguns: África do Sul, Alemanha, Austrália, Áustria, Bélgica, Birmânia, Canadá, Dinamarca, Espanha, Estados Unidos da América, Finlândia, França, Grã-Bretanha, Holanda, Irlanda, Israel, Itália, Malásia, Noruega, Nova Zelândia, Paraguai, Porto Rico, Portugal, Suécia e Uruguai (CORREIA, 1989, p. 90).

Por outro lado, há Estados que até reconhecem o direito à objeção de consciência, porém não o consagraram expressamente em suas legislações, como é o caso do Brasil (CORREIA, 1989 p. 90). A Lei Fundamental da Alemanha, de 1949, consagra o direito à objeção de consciência em seu artigo 4, no 3: "Ninguém será obrigado, contra sua consciência, a servir com armas na guerra. A regulação se fará por lei federal" (BUZANELLO, 2001, p. 45). Já a Constituição da Espanha, de 1978, no artigo $30, n^{\circ} 2$, assim determina "a lei fixará as obrigações militares dos espanhóis e regulamentará, com as devidas garantias, a objeção de consciência, assim como as demais causas de exceção do serviço militar obrigatório, podendo impor, em seu caso, uma prestação social substituta" (BUZANELLO, 2001, p. 45). A Constituição de Portugal, de 1976, e as sucessivas reformas mantiveram a objeção de consciência expressamente no art. $41, \mathrm{n}^{\circ} 6$, o qual dispõe: "É garantido o direito à objecção de consciência, nos termos da lei." A Constituição da Suécia, promulgada em 1975, estabelece (BUZANELLO, 2001, p. 45): no art. 12. Nenhuma restrição pode ser feita baseada tão somente em ideias políticas, religiosas, culturais ou outras congêneres.

$\mathrm{Na}$ França, a primeira lei a regulamentar a matéria da objeção de consciência foi a Lei de Recrutamento Militar, de 1963, representando um importante passo a respeito desse direito. Porém, em decorrência das críticas apresentadas devido às limitações e restrições advindas da referida lei, no sentido de admitir a objeção de consciência somente por motivos religiosos e filosóficos, surgiu em 1983 uma lei que alargou a todos e quaisquer motivos de consciência (CORREIA, 1989, p. 102-103).

Nos Estados Unidos da América, o reconhecimento tem antecedentes na Constituição de 1787. Três documentos legislativos tratam da objeção de consciência: Draft Act, de 1864 (Lei Recrutamento Militar); Draft Act, de 1917, e Selective Training and Service Act, de 1940. A objeção de consciência, assim como a desobediência civil, tem sido objeto de tamanha institucionalização 
que o Departamento de Justiça dos Estados Unidos, em 1967, criou órgãos administrativos específicos para tratar do tema (Special Hearing Office Conscientious Objectors e National Advisory Comissionon Civil Disorders), em razão de protestos públicos contra a convocação para a guerra do Vietnã (BUZANELLO, 2001, p. 45). Por fim, a Constituição italiana de 1947 estabeleceu, implicitamente, a objeção de consciência no artigo $52, n^{\circ} 2$, que está regulado na Lei $n^{\circ}$ 772, de 15 de dezembro de 1972 (BUZANELLO, 2001, p. 45). No mais, uma lei criada em 1993 sob o no 413 prevê a objeção de consciência na experimentação animal (LEVAl, 2001, p. 61).

\section{DA EXPERIMENTAÇÃO EM ANIMAIS}

Inicialmente, a experimentação animal é definida como toda e qualquer prática que utiliza animais para fins didáticos ou de pesquisa. Para Fernando Levai (2004, p. 63), esta prática "decorre de um erro metodológico que a considera o único meio para se obter conhecimento científico".

Nesse passo, os dois principais métodos utilizados para experimentação animal são a dissecação e a vivissecção. A dissecação é a separação, com instrumentos cirúrgicos, de partes do corpo ou órgãos de animais mortos para estudo de sua anatomia. Já a vivissecção é a prática de se realizar intervenções cirúrgicas em animais vivos com propósitos científicos (GREIF, 2003, p. 19). O termo "vivissecção" literalmente significa "cortar (um animal) vivo" (GREIF, 2000, p. 2).

No Brasil, a exemplo do que ocorre em quase todo o mundo, diariamente milhares de animais perdem a vida em experimentos cruéis, submetidos a testes cirúrgicos, toxicológicos, comportamentais, neurológicos, oculares, cutâneos, entre outros, sem que haja limites éticos, ou mesmo relevância científica, em tais atividades (LEVAI, 2001, p. 61). Na ótica do pesquisador os animais tornam-se eticamente neutros, como se fossem meros objetos descartáveis. Com efeito, ratos, coelhos, gatos, cães, rãs, macacos, porcos, cavalos, dentre outros animais, tornam-se cobaias nas mãos de pesquisadores, tanto de indústrias (cosméticas e farmacêuticas) quanto de centros de pesquisas e de faculdades das áreas biomédicas (LEVAI, 2001, p. 61).

\subsection{Retrospectiva Histórica da Experimentação Animal}

Tanto a vivissecção quanto a dissecação são práticas muito antigas. Vale dizer que experimentos com animais são realizados desde a Antiguidade.

Nessa senda, na Grécia Antiga a prática da experimentação em animais sobreveio devido à necessidade que os gregos tinham em buscar conhecimento e explicações racionais para os eventos que influenciavam as suas vidas. Soma-se a isto o fato de que na época imperava entre eles a teoria do antropocentrismo: considerava o homem o centro do universo. Ao proclamar a superioridade humana sobre tudo o que existe, grandes filósofos debruçaram-se unicamente sobre a questão do homem, como se a vida dos animais não tivesse valor (LEVAI, 2004, p. 18). 
Por conseguinte, métodos específicos para pesquisa foram desenvolvidos principalmente pelo filósofo grego Hipócrates (460-377 a.C.). Considerado "o pai da medicina", era admirado pelos também filósofos Platão e Aristóteles. Hipócrates já relacionava o aspecto de órgãos humanos doentes com o de animais, alegando propósitos didáticos (SEIXAS, 2010, p. 45).

Necessário ressaltar, ainda, que Aristóteles (384-322 a.C.), por ter sido o maior estudioso dos animais na Antiguidade, ficou conhecido como "o pai da Zoologia". Realizava seus estudos e pesquisas através da vivissecção e dissecação em animais (STORER, 2000, p. 276).

Outrossim, em sua obra "A política", Aristóteles refere que os animais são compostos de um sistema formado primeiro por uma alma e, depois, de um corpo, sendo que o corpo obedeceria a alma. Ele também diferencia o ser humano dos animais, no sentido de que os animais não participam de modo algum da razão, nem mesmo têm o sentimento dela e só obedecem às suas sensações. Aristóteles (2000, p. 12-14) acreditava que a natureza existia para um propósito, para um fim, sendo, assim, para benefício do homem.

Igualmente, anatomistas gregos como Alcmaeon de Cróton (500 a.C.), Diócles de Caristo (séc. V a.C.), Herófilo da Calcedônia (330-250 a.C.) e Erasístrato de Quios (305-240 a.C.) realizavam dissecações em animais com o objetivo de observar estruturas e formular hipóteses sobre o funcionamento destas. Posteriormente, o médico e filósofo romano Galeno de Pérgamo (129-210 d.C), baseado na medicina hipocrática, realizou importantes e revolucionários estudos, sendo considerado um dos pioneiros no uso da vivissecção de sua época (GREIF, 2000, p. 2).

$\mathrm{Na}$ Idade Moderna, os animais não humanos passaram a ser classificados como máquinas ou robôs, principalmente devido à teoria do francês René Descartes, no século XVII, segundo a qual os animais não possuíam alma nem mesmo capacidade de comunicação. Por isso, não poderiam ter a experiência da dor e do prazer, nem qualquer outra sensação ou emoção (FRANCIONE, 2007). Consequentemente, tornaram-se famosas as vivissecções de animais feitas pelos seus seguidores na Escola de Port-Royal, durante as quais os granidos dos cães seccionados vivos e conscientes eram interpretados não como um sinal de dor, e sim como um simples ranger de uma máquina. Foi o auge da teoria animal-máquina (LEVAI, 2004, p. 139).

Apesar disso, não é possível afirmar que a intenção desses cientistas era a de provocar sofrimento, afinal, viviam em uma época que se acreditava que as emoções e os sentimentos eram propriedades da alma e, portanto, exclusivamente humanas (MOREIRA, 2011).

Como demonstra o texto a seguir, nenhum cuidado era observado:

Os cientistas (cartesianos) espancaram cães com perfeita indiferença e fizeram pouco daqueles que sentiram pena das criaturas, como se elas não sentissem dor. Disseram que os animais eram relógios; que os gritos que 
emitiam quando surrados eram apenas o barulho de uma pequena mola que tinha sido tocada, mas que o corpo todo não tinha sentimentos. Pregaram, em tábuas, pelas patas, os pobres animais, para dissecá-los e ver a circulação do sangue, que era, então, tema de grande controvérsia. (Comentário de contemporâneo desconhecido de Descartes - séc. XVII.) (MASSON, 1998, p. 43-44).

Quase um século depois, indignado com tais ideias e preocupado com suas terríveis consequências, o filósofo iluminista francês François Marie Arouet, mais conhecido por Voltaire, contestou em sua obra "Tratado sobre a tolerância" o pensamento cartesiano (Ceticismo Metodológico) de Descartes (LEVAI, 2004, p. 139). Reafirmando a percepção de que os animais possuíam a capacidade de sentir dor, Voltaire assim explanou suas críticas:

É preciso, penso eu, ter renunciado à luz natural, para ousar afirmar que os animais são somente máquinas. Há uma contradição manifesta em admitir que Deus deu aos animais todos os órgãos do sentimento e em sustentar que não lhes deu sentimento.

Parece-me também que é preciso não ter jamais observado os animais para não distinguir neles as diferentes vozes da necessidade, da alegria, do temor, do amor, da cólera e de todos os seus afetos; seria muito estranho que exprimissem tão bem o que não sentem (VOLTAIRE apud LEVAI, 2004, p. 139).

Anos mais tarde, precisamente em 1789, o filósofo inglês Jeremy Benthan lança o livro Introduction to the principles of morals and legislation, no qual reforça a ideia de proteção aos animais. Benthan escreveu: "A questão não é, podem eles raciocinar? ou podem eles falar? Mas, podem eles sofrer?" (BENTHAN apud GOLDIM, 2011). Por outro lado, convém registrar que a dissecação de cadáveres humanos foi introduzida nas universidades nos séculos XII e XIII e se tornou prática comum em escolas de medicina. A crescente demanda por cadáveres humanos, devido ao aumento do número de escolas de medicina, porém, gerou problemas relacionados à aquisição destes cadáveres. Devido a esta situação, estudantes roubavam tumbas; eram chamados de "ressurreicionistas". O caso mais conhecido foi de William Burke e William Hare em Edimburgo, na Escócia, que em 1832 mataram pelo menos 16 pessoas para dissecação. Com isso, foi proibida a doação de cadáveres às escolas médicas (GREIF; TRÉZ, 2000, p. 3).

Impedidas de receber cadáveres humanos, as instituições de ensino passaram a se valer de animais, não porque representassem um bom modelo alternativo, mas porque não lhes era possível o acesso ao modelo humano. Em nome da facilidade de se obter animais, aliada à ausência de qualquer contestação sobre o seu uso, as gritantes diferenças anatômicas entre as espécies humana e animal foram então ignoradas (ORLANDI, 2011). 
Nesse tom, a vivissecção animal figurava, então, como metodologia padrão de investigação científica e de ensino da medicina. Os principais argumentos que contribuíram para a escolha deste modelo foram: que a vivissecção animal já era usada e consagrada como método de pesquisa e ensino, então não havia problema em continuar usando-a; a vida animal não tinha valor algum (a vida de alguns seres humanos também não tinha, mas escravos eram mais caros do que animais de criação); e, por fim, cadáveres humanos eram difíceis de se conseguir. Por derradeiro, a vivissecção animal continuou até os dias de hoje, não tendo sido suficientemente contestada (GREIF, 2003).

Em contrapartida, foi apenas no século XIX que o estudo sistemático da natureza ganhou impulso com as pesquisas de Alexander Von Humboldt (1769-1859) e Ernest Haeckel (1834-1919), conhecido como "pai da ecologia moderna". Fundamental, todavia, foi a contribuição de Charles Darwin, publicando "A origem das espécies" em 1859. Nesta obra, Darwin quebra crenças e tabus ao mostrar que todos os seres vivos - homens e animais integram a mesma escala evolutiva, possuindo modos peculiares de exprimir emoções e sentimentos. A partir desse estudo iniciou-se uma nova consciência, ensejando as primeiras discussões acadêmicas acerca dos direitos dos animais (LEVAI, 2004, p. 20-21).

Nessa linha, outros fatos marcantes contribuíram contra a sina servil dos animais como meros objetos de uso, diversão e consumo humano (LEVAl, 2004, p. 21), como, por exemplo, a criação das primeiras sociedades protetoras dos animais. A primeira foi a Society for the Preservation of Cruelty to Animals na Inglaterra, em 1824. A França também criou a Sociedade para a Proteção dos Animais em 1845. Sendo que, após estas, outras foram criadas nos Estados Unidos da América, Alemanha, Bélgica, Holanda e Áustria (CADAVEZ, 2008, p. 97).

Registra-se também que, em 1860, o fisiologista Claude Bernard utilizou o cão de estimação da sua filha em aula para os seus alunos. Em reação ao ocorrido, a esposa do fisiologista fundou a primeira associação em defesa dos animais utilizados em pesquisas. Tal situação foi fundamental para o estabelecimento de limites ao uso de animais no ensino (RAYMUNDO; GOLDIM, 2007).

A primeira lei a regulamentar o uso de animais em pesquisa foi proposta no Reino Unido, em 1876, através do British Cruelty to Animal Act. Em 1822, já havia sido instituída a Lei Inglesa Anticrueldade (British anticrueltyact). Nesse panorama, a primeira publicação norteamericana sobre aspectos éticos da utilização de animais em experimentação foi proposta pela Associação Médica Americana em 1909. Apesar disso, durante muitos anos as pesquisas que se utilizaram de modelos animais não foram fortemente questionadas devido ao seu alto impacto social, tais como as que possibilitaram o desenvolvimento das vacinas para raiva, tétano e difteria (RAYMUNDO; GOLDIM, 2007). 
Entretanto, filósofos contemporâneos do final do século $X X$ retomam a reflexão sobre o status moral e jurídico dos animais, considerando sua liberdade, sensibilidade e consciência. Conquanto os primeiros livros de ética em defesa dos animais apareceram a partir da década de 70, autores como Peter Singer, Richard Ryder, Tom Regan, John Harris, Andrew Linzey, por vezes com argumentos distintos, mas com vistas ao mesmo fim, têm se posicionado contra a experimentação animal, ocasionando, assim, o ressurgimento do debate sobre a utilização de animais em pesquisas e em outras atividades (FELIPE, 2007, p. 280).

Isso se deve principalmente à publicação do livro Libertação Animal, de Peter Singer, em 1975. A obra causou uma polêmica mundial, particularmente os relatos das condições a que os animais eram submetidos pela indústria de cosméticos e no processo de produção de alimentos (FELIPE IN: TRÉZ, 2008, p. 69-70).

Reforçando essa ideia, a autora Anamaria Feijó (2008, p. 138) refere que os animais não-humanos são titulares de direitos básicos, como a vida, tal direito é inerente e, por isso, não deveriam ser sacrificados em detrimento de outrem.

Portanto, descobertas científicas, principalmente na área da Biologia, associadas aos avanços da Medicina e benefícios na prática clínica propiciaram um aumento na utilização de animais como modelos experimentais pelo homem. Isto tem ensejado um repensar, sobretudo quanto às questões éticas relacionadas ao sofrimento animal, com repercussão também na área jurídica (CADAVEZ, 2008, p. 97).

\subsection{A Vivissecção como Método Didático Padrão}

Verifica-se que o testemunho da história revela que durante séculos - da Antiguidade até a época contemporânea - uma das mais cruentas demonstrações do poder e da insensibilidade humana tem sido a prática experimental sobre os animais (LEVAI; DARÓ, 2004, p. 138).

A utilização de animais como instrumentos na ciência geralmente é dividida em três categorias: educação, testes e pesquisa (REGAN, 2006, p. 200). Contudo, como já referido anteriormente, qualquer uma dessas três categorias decorre de um erro metodológico que considera a utilização de animais, para esses fins, o único meio para se obter conhecimento (LEVAI, 2004, p. 63). Nesse passo, a experimentação animal, pelo mal que causa às criaturas sencientes, não ofende só a moral, mas também prejudica a saúde humana. É o que tenta provar o movimento antivivisseccionismo científico que é formado, sobretudo, por médicos. Esse grupo luta para demostrar que essa prática baseia-se em erro metodológico, qual seja o de querer transferir os resultados das experiências com uma espécie animal para outra diversa, no caso a espécie humana (LEVAl; DARÓ, 2008, p. 51).

Com efeito, este método para fins didáticos vem sendo questionado em todo o mundo, tanto pela sociedade civil quanto por cientistas, profissionais, 
educadores e estudantes. A argumentação baseia-se em considerações éticas, metodológicas, psicológicas e ambientais, no sentido de substituir o uso de animais por técnicas mais inteligentes e responsáveis (GREIF, 2003, p. 23).

Como se sabe, tanto no campo didático quanto no científico, inúmeras experiências dolorosas são exaustivamente repetidas nos animais a fim de demostrar teses cujos resultados, muitas vezes, são notórios. Convém dizer que muitos desses estudos, afora sua inutilidade, revelam uma extrema indiferença dos vivisseccionistas pelo martírio dos animais utilizados, os quais, via de regra, acabam sendo mortos após uma considerável inflição de medo, dor e sofrimento (LEVAI, 2004, p. 67). Heron José (2009, p. 2) discordando da teoria de que o uso de animais está relacionado ao fato destes não possuírem a racionalidade que os seres humanos possuem. Ele afirma que se os deficientes mentais e os recém-nascidos também não possuem esse tipo de racionalidade, nem por isso nós cogitamos negar-lhes direitos ou dignidade moral.

Além disso, os vários experimentos didáticos realizados visam à observação de fenômenos fisiológicos e comportamentais a partir da administração de drogas e outras substâncias, a estudos comportamentais de animais em cativeiro, ao conhecimento da anatomia interna, ao desenvolvimento de habilidades e técnicas cirúrgicas, a estudos nutricionais, entre outros (MAGALHÃES; ORTÊNCIO FILHO, 2006, p. 149).

Por outro lado, as implicações éticas da vivissecção são de extrema importância e estão inseridas nos mais diversos ambientes, sobretudo na universidade, já que esta convive com a questão no seu cotidiano e possui a função de ser um espaço de reflexão e construção de novos paradigmas (SEIXAS, 2010, p. 45).

Nos Estados Unidos da América, por exemplo, anualmente, mais de seis milhões de animais são utilizados como recurso pedagógico. De acordo com relato de Tom Regan (2006, p. 201), animais são capturados nas florestas, adquiridos em abrigos de animais, roubados, gerados em estabelecimentos especiais ou comprados de abatedouros. A maioria deles passa por uma empresa de suprimentos biológicos antes de terminar na sala de aula. Vale dizer que o fornecimento de animais para fins de experimentação científica ou didática se revela nos Estados Unidos como uma indústria multimilionária.

Muito embora existam países que ainda se utilizam desse método como, por exemplo, o Brasil, há outros como a Argentina, Israel, os Países Baixos, a República Eslovaca e a Suíça, que eliminaram a prática nos ensinos fundamental e médio, sendo que na Grã-Bretanha, Alemanha e Suécia a prática foi completamente suprimida. Outrossim, as Universidades americanas de Columbia, Harvard, Johns Hopkins, Stanford e Yale não usam animais vivos, de nenhum modo e para nenhum fim (REGAN, 2006, p. 204).

Apenas nos últimos anos várias escolas superiores no Brasil vêm se empenhando na busca de alternativas à experimentação animal, como a 
Universidade de São Paulo, a Universidade Federal do Estado de São Paulo, a Universidade de Brasília, dentre tantas outras (LEVAI, 2004, p. 68).

Tais mudanças estão relacionadas com a ampliação das críticas em relação ao modelo animal, que aos poucos deixa de ser o meio utilizado para a assimilação dos conhecimentos trabalhados nas aulas dos cursos das áreas biomédicas. Assim, há uma diminuição cada vez maior no uso de animais, impulsionada pela descoberta de alternativas vantajosas, forte mobilização de estudantes que se opõem ao método de ensino que causa sofrimento aos animais, contradição nos valores que devem ser passados pelos educadores e restrições inclusas em diversas leis (PAIXÃO, 2001, p. 10-11).

Vale registrar o relato da experiência vivida pelo autor José Epifânio Lima em um experimento de vivissecção quando ainda curava a Graduação (2008, p. 26):

Durante este último experimento [...] o cão que seria operado pela turma do noturno assistia ao que era feito com seu companheiro de jaula durante a aula da tarde, estando acorrentado aos pés da mesa de cirurgia assustadíssimo, tremendo, com o rabo entre as pernas e apresentando diarreia nervosa, reação típica de pavor.

Igualmente, Peter Singer, em seu livro "Libertação animal", descreve inúmeras experimentações, bárbaras e cruentas, feitas com animais, e no fim desabafa (2008, p. 64):

Como podem [cientistas e pesquisadores] suceder estas coisas? Como podem pessoas que não são sádicas, passar seus dias de trabalho e arrastar macacos para uma depressão vitalícia, a aquecer cães até à morte, a transformar gatos em dependentes de drogas? Como podem eles depois de tirar as batas brancas, lavar as mãos e ir para casa, jantar com as famílias? Como podem os contribuintes permitir que seu dinheiro seja utilizado para financiar estas experiências? Como podem os estudantes manifestar-se contra a injustiça, a discriminação e a opressão de todos os tipos, seja a que distância for de sua casa, e ignorar a crueldade que era - e ainda é - levada a cabo nas suas faculdades?

Não obstante, resta demonstrado que são inúmeros os questionamentos quanto a real necessidade de utilizar a vivissecção como método didático padrão. Todavia, ainda há muitas universidades que rejeitam a possível substituição deste método por um modelo mais ético, sem prejuízos ao aprendizado, que não acarrete estresse e privação de liberdade ao animal e no qual o estudante não precise cortar, manipular e sacrificar animais sadios para tal fim (VIRGENS, 2011).

\section{A COLISÃO DE DIREITOS FUNDAMENTAIS}

O conflito entre normas no caso da objeção de consciência à experimentação animal com finalidade didática está compreendido entre o 
artigo 50, inciso VI, que dispõe sobre a liberdade de consciência, artigo 207, o qual confere autonomia didático-científica às universidades, bem como 0 artigo $225, \S 1^{\circ}$, inciso VII, o qual impõe a todos o dever de proteção à fauna, todos da Constituição Federal. Nesse tom, considerando tal conflito, o que prevalecerá? A garantia do direito à objeção de consciência ao estudante que se escusa em participar de aulas que utilizem o modelo animal como método de ensino, alegando afronta moral, ou a autonomia didático-científica da universidade como argumento levantado por esta para negar o direito à objeção? No caso do uso de animais, resta demonstrado que o choque entre normas se dá em âmbito constitucional, de um lado a liberdade de consciência e de outro os princípios gerais que norteiam a educação no país (MARASCHIN, 2007, p. 14).

O artigo 207 da Constituição brasileira dispõe que "As universidades gozam de autonomia didático-científica, administrativa e de gestão financeira e patrimonial, e obedecerão ao princípio de indissociabilidade entre ensino, pesquisa e extensão." (BRASIL, 1988) Para Moaci Carneiro (1998, p. 123), o objetivo da autonomia é assegurar a liberdade de crítica e a livre produção e transmissão do conhecimento, tornando as universidades impermeáveis a ingerências econômicas, políticas ou religiosas estranhas ao desenvolvimento do ensino, da pesquisa e da extensão, sendo que a detentora da autonomia é a comunidade acadêmica, a quem cabe a autogestão das atividades de ensino, pesquisa e extensão.

Nesse passo, vale frisar que pode parecer à primeira vista que o artigo 207 da Constituição confere às universidades poderes ilimitados. Porém, no caso da experimentação animal, ainda que as universidades aleguem deter a autonomia didático-científica, estas não podem se furtar da legislação que regulamenta tal prática. Dessa feita, considerando que 0 artigo $225, \S 1^{\circ}$, inciso VII, da Constituição Federal estabelece, entre outras coisas, que são vedadas, na forma da lei, as práticas que submetam os animais à crueldade, pode-se afirmar que as universidades, apesar de gozarem desta autonomia devem, ao praticar experiências com animais, sujeitar-se a este princípio. Nesse passo, incluir a proteção animal sob a tutela constitucional, o constituinte delimitou a existência de uma nova dimensão do direito fundamental à vida e do próprio conceito de dignidade da pessoa humana (MEDEIROS, 2004, p. 113). Em outras palavras, essas instituições não podem realizar tais pesquisas de forma indiscriminada e sem controle por parte da sociedade e do Estado (MAGALHÃES; DARÓ, 2008, p. 241-243). Segundo Nina Ranieri (1994, p. 22) "Qualquer que seja o enfoque, porém, clara é a conclusão de que autonomia, em direito público, constitui poder funcional derivado, circunscrito ao peculiar interesse da entidade que o detém e limitado pelo ordenamento geral que se insere, sem o qual, ou fora do qual, não existiria."

Além disso, ao atender plenamente o artigo 207 da Constituição Federal, poderia colocar-se em risco a liberdade de consciência dos alunos, sendo a liberdade de pensamento um dos direitos fundamentais constitucionais, 
assegurado dentro e fora das universidades. Nina Ranieri (1994, p. 34) refere, ainda, que as universidades têm o dever de cumprir uma função social, servindo à sociedade que as cria. Seria temerário, portanto, entregar um poder desmedido a um ente, exonerando-o do dever de prestar contas à sociedade a que pertence.

O princípio da autonomia das universidades (CF, art. 207) não é irrestrito, mesmo porque não cuida de soberania ou independência, de forma que as universidades devem ser submetidas a diversas outras normas gerais previstas na Constituição. Assim que o princípio da autonomia universitária é restrito e pode ser relativizado. LEVAI (2008, p. 444) assevera que o artigo 47, $\S 1^{\circ}$, da Lei $n^{\circ} 9.384 / 96^{7}$ garante às instituições de ensino, antes de cada ano letivo, a elaboração de programas dos cursos e demais componentes curriculares, sendo que esta fixação curricular deve observar as diretrizes gerais pertinentes (artigo 53, inciso $\|^{8}$ ), bem como o comando ético constitucional que veda a submissão de animais à crueldade, previsto na Carta Magna.

Por outro viés, cumpre registrar que pelo princípio da legalidade, não há lei que obrigue os estudantes à prática da vivissecção nas universidades. Não havendo obrigação a todos imposta, não há o que se falar em lei a ser descumprida. Por conseguinte, as universidades não podem, através da autonomia didático-científica, obrigar seus alunos objetores de consciência a realizar tais práticas (LEVAI, 2008, p. 441). Compartilha deste mesmo entendimento BASTOS (2004, p. 62) ao afirmar que "na redação atual, fica certo que em primeiro lugar há a possibilidade de invocação ampla da escusa de consciência", mas desde que feita valer para evadir-se o interessado da obrigação imposta a alguns ou a muitos, mas não a todos.

Nesse passo, a pessoa que se sinta constrangida a fazer ou deixar de fazer algo que contraria seus valores morais tem o direito de invocar a escusa de consciência, a não ser que haja alguma lei que a obrigue a tal prática ou omissão. Contudo, assim como não há lei que disponha ou regulamente a objeção de consciência à experimentação animal em universidades, também não há previsão legal que obrigue o estudante a realizar tais aulas. E, como se sabe, o consagrado princípio da legalidade, insculpido no artigo $5^{\circ}$, inciso II, da Constituição Federal (BRASIL, 1988), informa que: "Ninguém será obrigado

\footnotetext{
${ }^{7}$ Art. 47. Na educação superior, o ano letivo regular, independente do ano civil, tem, no mínimo, duzentos dias de trabalho acadêmico efetivo, excluído o tempo reservado aos exames finais, quando houver. $\S 1^{\circ}$ As instituições informarão aos interessados, antes de cada período letivo, os programas dos cursos e demais componentes curriculares, sua duração, requisitos, qualificação dos professores, recursos disponíveis e critérios de avaliação, obrigando-se a cumprir as respectivas condições. BRASIL. Lei $\mathrm{n}^{\circ}$ 9.394, de 20 de dezembro de 1996. Disponível em: <http://www.planalto.gov.br/ccivil_03/Leis/L9394.htm>. Acesso em: 11 mar. 2013.

${ }^{8}$ Art. 53. No exercício de sua autonomia, são asseguradas às universidades, sem prejuízo de outras, as seguintes atribuições: II - fixar os currículos dos seus cursos e programas, observadas as diretrizes gerais pertinentes. BRASIL. Lei ${ }^{\circ} 9.394$, de 20 de dezembro de 1996. Disponível em: <http://www.planalto.gov.br/ccivil_03/Leis/L9394.htm>. Acesso em: 11 mar. 2013.
} 
a fazer ou deixar de fazer alguma coisa senão em virtude de lei" (LEVAI, 2008, p. 444). De acordo com José Cretella Júnior (1997, p. 253), "A obrigação legal deve constar de lei a ser imposta a todos os que reúnem os mesmo requisitos." Cretella entende que, se por um lado a Constituição promete que ninguém será privado de direitos por motivos religiosos, filosóficos ou políticos, podendo crer e pensar no que quiser, ao mesmo tempo que assegura a manifestação pública de tais convicções, por outro lado não admite que alguém invoque quaisquer desses motivos para eximir-se de obrigação legal a todos imposta, como no caso do serviço militar, podendo sofrer rigorosas punições.

Ingo Wolfgang Sarlet (1996, p. 121) afirma que o processo de ponderação não se trata da atribuição de uma prevalência absoluta de um valor sobre o outro, mas sim na tentativa de aplicação simultânea e compatibilizada das normas, ainda que, no caso concreto, se torne necessária a atenuação de uma delas. Com uma prévia compreensão do conflito será, então, atribuído um peso específico para cada princípio ou norma em jogo.

Bruno Heringer (2007, p. 58) demonstra que a Suprema Corte Americana, a partir da decisão exarada no caso Sherbert na década de 50, passou a aplicar o balancing test (ponderação de interesses) à objeção de consciência. A ponderação, segundo aduz o autor, consiste em duas etapas: determinação da sinceridade das crenças do objetor e, caso seja provada esta, o ônus da prova da existência de um compelling state interest (interesse essencial e indeclinável) caberá ao indivíduo que negou o pedido de objeção.

Cabe ressaltar, ainda, que a técnica da ponderação foi utilizada para construção da decisão proferida pelo Juízo Federal de $1^{\circ}$ grau na ação judicial interposta por RóberBachinski contra a Universidade Federal do Rio Grande do Sul analisada no item anterior. Através da ponderação, o magistrado concluiu, no caso da objeção de consciência à experimentação animal, que a garantia constitucional de autonomia didático-científica das universidades fica limitado ao exercício de direitos considerados mais importantes, como o direito fundamental à liberdade de consciência, tendo em vista a convicção filosófica, ética e moral do aluno objetor. Entretanto, percebe-se que a autonomia didático-científica da instituição foi plenamente garantida quando o magistrado indeferiu o pedido genérico de impedir a universidade em realizar aulas práticas de vivissecção em animais, pelo fato de que seria uma decisão muito prejudicial e invasiva a este direito (BRASIL, 2008). O intérprete-aplicador, neste caso, realizou a ponderação dos bens envolvidos, visando a resolver a colisão através do sacrifício mínimo dos direitos em questão (FARIAS, 1996, p. 98).

Não há dúvida de que existem direitos mais valiosos que outros e que nem todos se encontram em idêntica hierarquia. Estes direitos, por sua vez, como a liberdade de consciência, relacionam-se com o poder-dever que todo o cidadão possui de defendê-los - através da objeção de consciência. A liberdade de consciência e os princípios educacionais aqui confrontados 
são direitos de diferentes níveis: a liberdade de consciência vale ou pesa mais, especialmente nas situações em que os princípios educacionais não estão em perigo tanto quanto a liberdade de consciência, que corre o risco de ser violentada inutilmente, não para salvar um bem mais elevado ou afastar um perigo para a sociedade (MARASCHIN, 2007, p. 14).

\section{CONCLUSÃo}

Em vista dos argumentos apresentados, verifica-se que a experimentação animal com finalidade didática se tornou obsoleta devido à criação e desenvolvimento de métodos alternativos. Muito embora a maioria dos estudantes das áreas biomédicas perceba a vivissecção como algo desconfortável e agressivo; ainda alguns docentes a consideram uma espécie de mal necessário, tendo em vista, principalmente, a falta de conhecimento da existência dos métodos substitutivos.

Observou-se que em diversos países a vivissecção foi completamente substituída, e isso se deve à evolução consciencial do homem, bem como às mudanças nas legislações de tais países, que passaram a prever a aplicação dos métodos alternativos à experimentação animal. Outrossim, em que pese a Lei de Crimes Ambientais brasileira (Lei $n^{\circ}$ 9.605/98), em seu artigo 32, considerar crime o uso de animais em experiências no caso da existência de métodos substitutivos, houve a regulamentação do parágrafo primeiro do inciso VII do artigo 225 da Constituição Federal de 1988 pela Lei no 11.794/08, que dispõe sobre procedimentos para o uso cientifico de animais.

O que é preocupante, é que a lei de 2008, não incentiva os pesquisadores a desenvolver metodologias substitutivas ao uso de animais, no sentido de contribuir para a construção de um novo paradigma, à luz da proteção aos valores constitucionalmente assegurados.

Essa lei cria ainda, o CONCEA (Conselho Nacional de Controle de Experimentação Animal), com poder normativo, consultivo, deliberativo e recursal, a fim de regulamentar procedimentos para instalação e funcionamento de centros de criação, de biotérios e de laboratórios de experimentação animal. Ele integra o Ministério da Ciência e Tecnologia, e ainda não foi motivo de debates acadêmicos relevantes.

Assim, entende-se que o direito a escusa de consciência, por ser um direito fundamental, deve prevalecer a partir de uma interpretação constitucional mais adequada, conforme demonstrado nesse estudo.

Corrobora esse entendimento, o fato de faculdades respeitadas, como a Universidade de São Paulo, a Universidade Federal do Estado de São Paulo, a Universidade de Brasília, dentre tantas outras, não utilizarem mais a vivissecção. Inúmeras experiências dolorosas e cruéis são realizadas e repetidas em animais diariamente, cujos resultados, muitas vezes, são óbvios. Isso demonstra, além da sua desnecessidade, uma indiferença dos vivisseccionistas pelo sofrimento dos animais, sendo que a morte para estes animais se torna um alívio. 
Por outro viés, verifica-se que a indiferença ou mesmo a falta de questionamento por parte de alguns acadêmicos que presenciam a vivissecção, se deve à diminuição da sensibilidade devido à familiaridade com a experimentação animal, o que os leva a perder o sentido de respeito à vida dos animais.

Além disso, nos últimos anos, o bem estar dos animais vem sendo valorizado devido a uma mudança de pensamento de antropocentrismo materialista para biocentrismo ou ecocentrismo. Por muitos anos o uso da teoria cartesiana embasou a defesa pela manutenção do modelo animal por considerar que os animais eram simples máquinas insensíveis. Contudo, diversas perspectivas morais e éticas se abriram, contrariando o referido argumento. Esses fundamentos morais e éticos defendem que os animais, além de terem instinto, são seres sencientes, dotados de inteligência, bem como pregam a extensão dos direitos fundamentais estabelecidos aos seres humanos para atender o caso dos animais, considerando que a destinação de direitos aos homens não se deve à sua condição de ser humano, mas sim para melhorar a sua condição de vida.

Nesse passo, destoando dos que aceitam a realização da vivissecção em animais não humanos, alguns estudantes objetores de consciência, embasados em uma disposição de valores e princípios, com relação a não agredir, torturar, provocar dor e sofrimento intensos a outros seres humanos ou não, têm o direito de se escusarem de participar das aulas que utilizem o modelo animal como método de ensino a fim de não afrontar suas consciências.

Logo, o presente estudo tentou demonstrar que a objeção de consciência se fundamenta na possibilidade do sujeito em não cumprir obrigações ou realizar certos atos que conflituem com os ditames de sua consciência. $\mathrm{O}$ direito fundamental à liberdade de consciência (artigo $5^{\circ}$, inciso $\mathrm{VI}$, da Constituição Federal) como núcleo da objeção de consciência, garante o respeito e proteção do livre desenvolvimento da personalidade do indivíduo que, inserido em uma sociedade pluralista, exterioriza suas percepções éticas e morais através de seus atos.

As justificativas para o reconhecimento da objeção de consciência podem ser de diversas ordens, como política, jurídica ou moral. Entretanto, estas justificativas devem revestir-se de grau bastante forte embasadas em valores morais, igualando a objeção a um estado de necessidade do indivíduo. Nesse prisma, observa-se que quando a vivissecção ofende as convicções filosóficas ou morais do aluno, ele não deve ser forçado a realizar tais aulas, considerando que a opção de aderir ou não a esta metodologia deve ser assegurada ao estudante, facultando a este, em contrapartida, a realização de trabalhos alternativos.

Igualmente, apesar de a Constituição Federal fazer referência específica apenas ao direito à objeção de consciência ao serviço militar (artigo 143, § $1^{\circ}$ ), as outras formas de objeção estão compreendidas no artigo $5^{\circ}$, inciso VIII, 
sendo que este direito, mesmo que precário o seu reconhecimento pelo constituinte, reclama efetividade. O artigo $5^{\circ}$, inciso VIII, da Constituição Federal dispõe que ninguém será privado de direitos por motivo de crença religiosa ou de convicção filosófica ou política, salvo se as invocar para eximir-se de obrigação legal a todos imposta e recusar-se a cumprir prestação alternativa, fixada em lei, porém, no caso da experimentação animal com fins didáticos não há lei que obrigue a realização da vivissecção. Dessa maneira, o estudante pode invocar a escusa de consciência quando esta prática contrariar seus valores morais, levando-se em consideração o princípio da legalidade, que prevê que ninguém será obrigado a fazer ou deixar de fazer algo senão em virtude da lei. Verifica-se que,assim como não há lei que disponha ou regulamente a objeção de consciência à experimentação animal, também não há previsão legal que obrigue o estudante a realizar tais aulas.

Quanto ao conflito entre normas constitucionais, no caso da experimentação animal, este pode ser solucionado através da técnica da ponderação e do princípio da proporcionalidade. Nesse passo, observa-se que mesmo que as universidades possuam a autonomia didático-científica, essa autonomia encontra limites em direitos mais relevantes, como o direito fundamental à liberdade de consciência e a proteção aos animais. Com efeito, não é possível atender plenamente a garantia de autonomia didático-científica das instituições de ensino, pois poderia colocar-se em risco a liberdade de consciência dos alunos, sendo a liberdade de pensamento um dos direitos fundamentais constitucionais assegurados dentro e fora das universidades.

\section{REFERÊNCIAS}

ARISTÓTELES. A Política. 2. ed., São Paulo: Nacional, 2000.

BASTOS, Celso Ribeiro; MARTINS, Ives Gandra da Silva. Comentários à Constituição do Brasil (promulgada em 5 de outubro de 1988): arts. 5 a 17. 3. ed., São Paulo: Saraiva, 2004.

BASTOS, Celso Ribeiro; PFLUG, Samantha Meyer. Do Direito Fundamental à Liberdade de Consciência e de Crença. Revista de Direito Constitucional e Internacional: Cadernos de Direito Constitucional e Ciência Política, v. 9, nº 36, 2001.

BITTAR, Carlos Alberto. Os Direitos da Personalidade. 4. ed., Rev. ampl. e atual. Rio de Janeiro: Forense Universitária, 2000.

BOBBIO, Norberto. O Futuro da Democracia. 7. ed., São Paulo: Paz e Terra, 2000.

BRASIL. Vara Federal Ambiental, Agrária e Residual da Subseção Judiciária de Porto Alegre. Sentença prolatada em Ação Ordinária 2007.71.00.019802-0. Autor: Róber Freitas Bachinski. Ré: Universidade Federal do Rio Grande do Sul - UFRGS. Juiz Federal: Cândido Alfredo Silva Leal Júnior. Publicação: 19.05.2008. Disponível em: <http://www.trf4.jus.br/trf4/processos/visualizar_documento_gedpro.php?local=jfrs\& documento $=3312740 \&$ DocComposto $=\&$ Sequencia $=\&$ hash $=5 \mathrm{~b} \bar{b} a 4665 \mathrm{e} 7 \mathrm{fb} 831406 \mathrm{ec} 569$ 75cfe58db>. Acesso em: 10 mar. 2013.

BRASIL. Constituição (1988). Constituição da República Federativa do Brasil de 1988. Disponível em: <http://www.planalto.gov.br/ccivil_03/constituicao/constituiçao.htm>. Acesso em: 12 mar. 2013. 
BRASIL. Lei no 9.394, de 20 de dezembro de 1996. Disponível em: <http://www.planalto. gov.br/ccivil_03/Leis/L9394.htm>. Acesso em: 17 mar. 2013.

BRASIL. Resolução no 08, de 12 de junho de 1991. Disponível em:<http://portal.crbio02.gov.br/Legislacoes.Aspx?N=9>. Acesso em: 11 mar. 2013.

BUZANELLO, José Carlos. Direito de Resistência Constitucional. 2. ed., Rio de Janeiro: Lumen Juris, 2006.

. Objeção de Consciência: um direito constitucional. Revista Jurídica Consulex: Caso Galdino o desfecho de uma tragédia, Brasília, Consulex, v. 5, nº 117, 2001.

CADAVEZ, Lília Maria V. Crueldade contra Animais: uma leitura transdisciplinar à luz do sistema jurídico brasileiro. Direito \& Justiça (Porto Alegre), Porto Alegre, v. 34, $\mathrm{n}^{\circ} 1$, p. 88-120, jan./jun. 2008.

CARNEIRO, Moaci Alves. LDB Fácil: leitura critico-compreensiva artigo a artigo. 3. ed., Petrópolis: Vozes, 1998.

CORREIA, António Damasceno. O Direito à Objeção de Consciência. Coleção Vega Universidade Lisboa: Vega, 1989.

CRETELLA JúNIOR, José. Comentários à Constituição Brasileira de 1988: Art. $1^{\circ}$ a 5, I a LXVII. 3. ed., Rio de Janeiro: Forense Universitária, 1997.

FARIAS, Edilsom Pereira de. Colisão de Direitos: a honra, a intimidade, a vida privada e a imagem versus a liberdade de expressão e informação. Porto Alegre: Sérgio Antônio Fabris, 1996.

FEIJÓ, Anamaria Gonçalves dos Santos. A Dignidade e o Animal Não-humano. In MOLINARO, Carlos Alberto; MEDEIROS, Fernanda Luiza Fontoura de; SARLET, Ingo Wolfgang; FENSTENSEIFER, Tiago (Org.). A Dignidade da Vida e os Direitos Fundamentais para Além dos Humanos: uma discussão necessária. Belo Horizonte: Fórum, 2008.

FELIPE, Sônia T. Ética e Experimentação Animal: fundamentos abolicionistas. Florianópolis: Ed. da UFSC, 2007.

. O Estatuto dos Animais usados em Experimentos: da negação filosófica ao reconhecimento jurídico. In: TRÉZ, Thales (Org.). Instrumento Animal: o uso prejudicial de animais no ensino superior. Bauru: Canal 6, 2008. p. 69-70.

FERREIRA FILHO, Manoel Gonçalves. Curso de Direito Constitucional. 35. ed., São Paulo: Saraiva, 2009.

. Direitos Humanos Fundamentais. 9. ed., rev. São Paulo: Saraiva, 2007.

FRANCIONE, G. L. Vivissecção, parte 2: a justificativa moral da vivissecção. Ediciones Anima, 2007. Disponível em: <http://www.anima.org.ar/libertacao/abordagens/ a-justificativa- moral-vivisseccao.html>. Acesso em: 10 mar. 2013.

GOLDIM, José Roberto; RAYMUNDO, Márcia Mocellin. Aspectos Históricos da Pesquisa com Animais. Disponível em: <http://www.ufrgs.br/bioetica/animhist.htm>. Acesso em: 10 mar. 2013.

GORDILHO, Heron José de Santana. Abolicionismo Animal. Disponível em: $<$ http://www.abolicionismoanimal.org.br/artigos/abolicionismoanimal.pdf>. Acesso em: 15 set. 2013.

GREIF, Sérgio. Alternativas ao Uso de Animais Vivos na Educação pela Ciência Responsável. 1. ed., São Paulo: Instituto Nina Rosa, 2003. 
; TRÉZ, Thales. A Verdadeira Face da Experimentação Animal. Rio de Janeiro: Sociedade Educacional "Fala Bicho", 2000.

HERINGER, Bruno Júnior. A Liberdade de Consciência na Constituição. In: CARVALHO, Salo de (Org.). Leituras Constitucionais do Sistema Penal Contemporâneo. Rio de Janeiro: Lumen Juris, 2004.

. Objeção de Consciência e Direito Penal: justificação e limites. Rio de Janeiro: Lumen Juris, 2007.

HOUAISS, Antonio; VILLAR, Mauro; FRANCO, Francisco Manoel de Mello. Dicionário Houaiss da Língua Portuguesa. 1. ed., Rio de Janeiro: Objetiva, 2009.

LEVAI, Laerte Fernando. Direito dos Animais. 2. ed., Campos do Jordão: Mantiqueira, 2004.

O Direito à Escusa de Consciência na Experimentação Animal. In: MOLINARO, Carlos Alberto (Org.) et. al. A Dignidade da Vida e os Direitos Fundamentais para Além dos Humanos: uma discussão necessária. Belo Horizonte: Fórum, p. 429-450, 2008.

DARÓ, Vânia Rall. Experimentação Animal: histórico, implicações éticas e caracterização como crime ambiental. Revista de Direito Ambiental, São Paulo, Revista dos Tribunais, v. 9, nº 36, p. 138-150, out./dez. 2004.

. Experimentação Animal: histórico, implicações éticas e caracterização como crime ambiental. In: TRÉZ, Thales (Org.). Instrumento Animal: o uso prejudicial de animais no ensino superior. Bauru: Canal 6, 2008.

LEVAI, Tamara Bauab. Vítimas da Ciência: limites éticos da experimentação animal. 1. ed., Campos do Jordão, SP: Mantiqueira, 2001.

LIMA, José Epifânio Regis. Vozes do Silêncio: cultura científica: ideologia e alienação no discurso sobre vivissecção. 1. ed., São Paulo: Instituto Nina Rosa, 2008.

MAGALHÃES, Marcos; ORTÊNCIO FILHO, Henrique. Alternativas ao Uso de Animais como Recurso Didático. Arq. Ciênc. Vet. Zool. Unipar, Umuarama, v. 9, nº 2, p. 147-154, 2006.

MAGALHÃES, Valéria B.; DARÓ, Vânia Rall. Ciência e Poder: pesquisas com animais e autonomia universitária. Revista Brasileira de Direito Animal, ano 3, v. 4. p. 231-246, jan./dez. 2008.

MARASCHIN, Cláudio. A Objeção de Consciência como Direito Fundamental a não Utilização de Animais em Experimentos Científicos ou Pedagógicos. In: SEMANA DE EXTENSÃO, PESQUISA, E PÓS-GRADUAÇÃO, 03 nov. 2007. Anais... Porto Alegre: UniRitter, 2007.

MARMELSTEIN, George. Curso de Direitos Fundamentais. 2. ed., São Paulo: Atlas, 2009. MASSON, Jeffrey Moussaieff; MCCARTHY, Susan. Quando os Elefantes Choram: A vida emocional dos animais. São Paulo: Geração Editorial, 1998.

MEDEIROS, Fernanda Luiza Fontoura. Meio Ambiente: direito e dever fundamental. Porto Alegre: Livraria do Advogado, 2004.

MIRANDA, Francisco C. Pontes de. Comentários à Constituição de 1946. t. 4. Rio de Janeiro: Borsoi, 1963.

MORA, José Ferrater. Dicionário de Filosofia. V. 1, 3. ed., São Paulo: Martins Fontes, 1998. MORAES, Alexandre de. Direitos Humanos Fundamentais: teoria geral: comentários aos arts. $1^{0}$ à $5^{\circ}$ da Constituição da República Federativa do Brasil: doutrina e jurisprudência. 7. ed., São Paulo: Atlas, 2006. 
MOREIRA, Herilckmans Belnis et. al. Uma Visão da Experimentação Animal nos Cursos de Graduação: formação acadêmica x experimentação animal. Disponível em: <http://www.oocities.org/exp_animal/Pesquisa.htm>. Acesso em: 09 mar. 2013.

MORIN, Edgar. Os Sete Saberes Necessários à Educação do Futuro. 2. ed., São Paulo: Cotez; Brasília, DF: UNESCO, 2001.

ORLANDI, Vanice Teixeira. Vivissecção. Disponível em: <http://www.direitoanimal.org/ onealltextos.php?one=24>. Acesso em: 06 mar. 2013.

PAIXÃO, Rita Leal. Experimentação Animal: razões e emoções para uma ética. Tese (Doutorado) - Fundação Oswaldo Cruz, Rio de Janeiro, 2001.

RANIERI, Nina. Autonomia Universitária: as Universidade Públicas e a Constituição Federal de 1988. São Paulo: Ed. USP, 1994.

RAYMUNDO, M. M.; GOLDIM, J. R. O Uso de Animais em Pesquisas Científicas. Disponível em: <http://www.sorbi.org.br/revista4/animais-2007.pdf>. Acesso em 11 mar. 2013.

RAWLS, John. Uma Teoria da Justiça. Tradução de Almiro Pisetta e Lenita M. R. Esteves. São Paulo: Martins Fontes, 1997.

REGAN, Tom. Jaulas Vazias: encarando o desafio dos direitos animais. Porto Alegre: Lugano, 2006.

SARLET, Ingo Wolfgang. Dignidade da Pessoa Humana e Direitos Fundamentais. 2. ed., rev. e amp. Porto Alegre: Livraria do Advogado, 2002.

. Valor de Alçada e Limitação ao Duplo Grau de Jurisdição - Problematização em nível constitucional à luz de um conceito de Direitos Fundamentais. AJURIS: Revista Ajuris, Porto Alegre, p. 85-130, v. 23, nº 66, mar. 1996.

SEIXAS, Mone M. et. al. Consciência na Substituição do Uso de Animais no Ensino: aspectos históricos, éticos e de legislação. Revista Brasileira de Direito Animal, Salvador, BA: Evolução, ano 5, v. 6, jan./jun. 2010.

SILVA, José Afonso da. Curso de Direito Constitucional Positivo. 30. ed., Rev. e atual. São Paulo: Malheiros, 2008.

SINGER, Peter. Libertação Animal. 2. ed., Porto Alegre: Lugano, 2008.

STORER, Tracy; USINGER, Robert. Zoologia Geral. 6. ed., São Paulo: Nacional, 2000. VIRGENS, João Henrique A. Substituição do Uso de Animais como Recurso Didático. Disponível em: <http://www.abolicionismoanimal.org.br/artigos/substitui_odousodeanimais comorecursodidtico.pdf>. Acesso em: 10 mar. 2013. 